REGARDS

SUR L'ECONOMIE ALLEMAND

BULLETIN ECONOMIQUE DU CIRAC
Regards sur l'économie allemande

Bulletin économique du CIRAC

$88 \mid 2008$

Varia

\title{
Revenus : 65 \% des 18-64 ans vivent de leur travail
}

Isabelle Bourgeois

\section{CpenEdition}

Journals

Édition électronique

URL : http://journals.openedition.org/rea/1703

DOI : 10.4000/rea.1703

ISBN : 978-2-8218-0872-0

ISSN : 1965-0787

Éditeur

CIRAC

Édition imprimée

Date de publication : 1 octobre 2008

Pagination : 38

ISSN : 1156-8992

Référence électronique

Isabelle Bourgeois, «Revenus : $65 \%$ des 18-64 ans vivent de leur travail », Regards sur l'économie allemande [En ligne], 88 | octobre 2008, mis en ligne le 01 octobre 2010, consulté le 15 septembre 2020. URL : http://journals.openedition.org/rea/1703

Ce document a été généré automatiquement le 15 septembre 2020.

(C) CIRAC 


\title{
Revenus : 65 \% des 18-64 ans vivent de leur travail
}

\author{
Isabelle Bourgeois
}

1 En 2007, près des deux tiers (65\%) des adultes tiraient leurs revenus essentiellement d'une activité professionnelle, soit 33,8 millions d'Allemands de 18 à 64 ans sur les 51,7 millions recensés outre-Rhin dans cette tranche d'âge. Ce nombre a augmenté depuis 2006 (un demi million d'individus de plus). Rapportée à l'ensemble de la population allemande, la part de ces 'actifs' est ainsi passée de $41 \%$ à $42 \%$. C'est ce que révèle la dernière étude Mikrozensus dont Destatis a publié quelques extraits le 15 août dernier. Les hommes sont plus nombreux (74 \%) à vivre de leur travail que les femmes (57 \%).

2 Quant au nombre d'Allemands de 18-64 ans vivant de revenus de transfert (hors pensions de retraite), il est de 5,5 millions en 2007 , soit $11 \%$ de ce groupe d'âge ou $7 \%$ de la population totale (82,3 millions). Leur nombre s'est réduit de 320000 en un an. Par ailleurs, dans le même groupe d'âge, $8 \%$ des hommes et $25 \%$ des femmes vivent du soutien de leur famille. Dans la population totale, ils sont aujourd'hui 23 millions (400 000 de moins qu'en 2006).

3 Le groupe des Allemands de plus de 65 ans vit presque exclusivement des pensions de retraite. Le nombre des retraités a légèrement augmenté en un an $(+130000)$, passant à 18,5 millions, soit $22 \%$ de la population. Parmi les hommes de plus de 65 ans, on recense $96 \%$ de retraités, une part plus faible chez les femmes (84\%). En effet, $13 \%$ des Allemandes de plus de 65 ans tirent leurs revenus du cercle familial. (IB) 


\section{INDEX}

Mots-clés : actif, activité professionnelle, conditions de vie, population active, emploi, revenu, salaire, travail 